\title{
Anomalous spelling in Byelorussian: the replacement of e by $a$ in post-stress sylables
}

\author{
BY
}

\author{
P. J. MAYO
}

A distinctive feature of the Byelorussian literary language is akańnie, i.e. the pronunciation of unstressed [o], [e] (and [a]) as [a] in the following positions: word initial e.g. абыхо́д [abyxót], in the immediate pretonic syllable e.g. дамы [damý], in a final open syllable e.g. вóкa [vóka]. In other unstressed positions - syllables preceding the stress other than the immediate pretonic syllable and post-stress syllables other than final open - reduction of the vowel takes place to [ъ] e.g. гарады [ $\gamma$ ъadý], го́радам [ $\gamma$ órъdъm].

A similar situation may be observed where unstressed [o], [e] (and [a]) occur after soft consonants. ${ }^{1}$ They are pronounced [a] in the immediate pretonic syllable e.g. лясы [1'asý] and in a final open syllable e.g. по́ле [pól'a]. Elsewhere there is vowel reduction to [i] е.g. веліза́рны [v'ilizárny], во́сень [vóśiń]. The jotated vowel [je] occurring initially in a word in the immediate pretonic syllable is pronounced [ja] e.g. яго́ [ja`ó]. ${ }^{1}$

However, in Byelorussian as in many other languages, spelling is slow to reflect the realities of pronounciation. Despite the fact that the modern orthography, embodying proposals put forward by the Byelorussian Academy of Sciences, was agreed upon as recently as $1933,{ }^{2}$ the phonetic situation outlined above, while more accurately reflected than is the case with akannie and vowel reduction in Russian, is nevertheless only imperfectly represented. According to the Decree of 28 August 1933 a was to be written for unstressed o, 9 in all unstressed syllables (whether those in which akannie takes place or those with vowel reduction), while a was to replace e (ë) in unstressed position only in the immediate pretonic syllable e.g. зямля́, while in other unstressed positions e was to remain unchanged e.g. веліза́рны (e occurs two syllables prior to the stress); выехаць, ду́маеце (e in post-stress syllables). ${ }^{3}$

At first sight these limitations on the replacement of unstressed e (e) by $\mathrm{g}$ would seem to be an accurate reflection of the reality of the situation in modern Byelorussian, since they are in practice supported by numerous examples e.g. спе́шна - няспе́шна, све́жы - нясве́жы but вялі́кі - невялі́кі, спако́йны - неспако́йны; ва́жкасць - бязва́жкасць but адка́знасць - безадка́знасць; е́хаць - выехаць; нясу́ — нясе́ш — нясе́ — нясём - нясу́ць but несяце́ etc. Certainly this is the orthographical rule most frequently encountered in textbooks and grammars dealing with the modern Byelorussian literary language. ${ }^{4}$

Closer examination, however, reveals instances of anomalous spelling. These are to be found in certain inflexional endings of nouns and adjectives, and all involve the use of $g$ for unstressed $e$ (ë) in post-stress syllables. ${ }^{5}$ 
In nouns this phenomenon is most widespread in the genitive plural ending -яy̆, the unstressed ending for nouns with a soft final stem consonant. It is used for such nouns in all the declensions, but not for all such nouns in any given declension. Most commonly it occurs in nouns of the o-stem ${ }^{6}$ declension, where it is basic and whence it has spread to the other declensions, often as an alternative. Examples:

\begin{tabular}{|c|c|c|c|c|}
\hline$o$-stem & nom. sing. & $\begin{array}{l}\text { ге́ній } \\
\text { сусе́д } \\
\text { пралета́рый } \\
\text { здарэнне } \\
\text { узго́р’e }\end{array}$ & gen. pl. & $\begin{array}{l}\text { ніяў } \\
\text { ссе́дзяў } \\
\text { ралета́рыяў } \\
\text { дарэнняў } \\
\text { зго́р'яў }\end{array}$ \\
\hline$a$-stem & nom. sing. & $\begin{array}{l}\text { пе́сня } \\
\text { я́бльпня } \\
\text { зямля́ }\end{array}$ & $\begin{array}{l}\text { пе́сняў } \\
\text { я́бльняй } \\
\text { зе́мляў }\end{array}$ & $\begin{array}{l}\text { (also пе́сень) } \\
\text { (also я́бльнь) } \\
\text { (also зяме́ль) }\end{array}$ \\
\hline$i$-stem & nom. sing. & $\begin{array}{l}\text { сенажа́ць gen.pl. } \\
\text { я́касць } \\
\text { верфь }\end{array}$ & $\begin{array}{l}\text { сенажа́цяў } \\
\text { я́касцяў } \\
\text { ве́рффяў }\end{array}$ & \\
\hline
\end{tabular}

The explanation of the use of $я$ for unstressed e (ë) in the genitive plural of nouns in contravention of the orthographical rule is clearly one of analogy. For o-stem nouns with a hard final stem consonant the endings of the genitive plural are -oy̆ (stressed) and -ay̆ (unstressed). Nouns with a soft final stem consonant and stress on the ending in the genitive plural have -ëy̆. In accordance with the orthographical rules of Byelorussian one would expect the equivalent unstressed ending to be written -ey̆, ${ }^{7}$ but instead we find -яy̆. The opposition in the hard variety of the declension between -oy̆ (stressed) and -ay̆ (unstressed) has provided the impetus towards a corresponding opposition in the soft variety between -ëy̆ (stressed) and -яy̆ (unstressed). At the same time the opposition between the two endings -oy̆ (hard) and -ëy̆ (soft) leads to a corresponding opposition between the two unstressed endings -ay̆ (hard) and -яy̆ (soft). To put it another way:

$$
\begin{aligned}
& \text { As -oy̆ (hard stressed) is to -ay̆ (hard unstressed) } \\
& \text { so -ëy̆ (soft stressed) is to -яy̆ (soft unstressed) }
\end{aligned}
$$

and as -oy̆ (hard stressed) is to -ëy̆ (soft stressed)

$$
\text { so -ay̆ (hard unstressed) is to -gy̆ (soft unstressed). }
$$

It is clear that what we are dealing with here is an ending which has become morphologised, i.e. treated as a grammatical form independent of the phonetic development and orthographical rules applying to Byelorussian in general.

The same pattern is to be seen in the ending of the instrumental singular of $a$-stem nouns. Here the endings are:

Hard: stressed -ой, unstressed -ай

Soft: stressed -ёй, unstressed -яй 
with \& again appearing for unstressed ë in a post-stress position. Examples:

Hard stressed: nom. sing. вадá

Hard unstressed: nom. sing.

Soft stressed: nom. sing.

Soft unstressed: nom. sing.

$$
\text { пара́ }
$$$$
\text { брыга́да }
$$$$
\text { фа́брыка }
$$

зямля́

суддзя́

пе́сня

ста́нцыя instr. sing. вадо́й паро́й

брыга́дай

фа́брыкай

instr. sing. зямлёй

суддзёй

пе́сняй

ста́нцыяй

In two other inflexional endings of the noun declensions where one might expect a comparable analogical development it does not in fact take place. The endings concerned are the instrumental singular of masculine and neuter nouns of the $o$-stem declension (and, by extension, of the consonant stem declension where it adapts its endings to the $o$-stem declension) and the nominative/accusative singular of neuter nouns of the same declension.

In the first of these instances it is difficult to understand why a comparable development to that of the genitive plural and of the instrumental singular of $o$-stem nouns does not take place, since one has exactly the same opposition between the vowels of the hard stressed (-om) and hard unstressed (-am) endings, and between the hard stressed (-OM) and soft stressed (-ëm) endings, which lead to the use of $я$ for e (ë) in the soft unstressed endings described above. The fact remains, however, that $\mathrm{g}$ does not replace e (ë) in this ending. ${ }^{8}$

In the second instance - the nominative/accusative singular of the 0 -stem declension - the fact that $\&$ does not replace unstressed e (ë) is, to some degree at least, more readily explained. It is a fact that in no inflexional ending (whether of noun, adjective, pronoun or verb) in Byelorussian is a final e replaced by a despite the existence of the same conditions of opposition between hard stressed and hard unstressed or between hard stressed and soft stressed endings as obtain in the situations dealt with above. As far as the nominative/ accusative singular of neuter nouns of the o-stem declension is concerned this leaves us with the following set of endings: ${ }^{9}$

$$
\begin{array}{ll}
\text { Hard stressed -o e.g. акно́ } \\
\text { unstressed -a e.g. во́зера } \\
\text { Soft } \\
\text { stressed -ë e.g. набыццё } \\
\text { unstressed -e e.g. пыта́нне }
\end{array}
$$

In the adjective declension the inflexional endings with anomalous spelling are the following: neuter nominative/accusative singular (-яe), masculine and neuter genitive singular (-яга) and dative singular (-ямy), feminine genitive (-яе/-яй), dative (-яй), instrumental (-яю/-яй) and prepositional (-яй) singular, all of adjectives with a soft final stem consonant.

As in the case of anomalous spelling in the inflexional endings of nouns these endings should be regarded as morphologised, although unlike the noun declension system the declension system of adjectives does not have a complete set of contrasts to help this process along, 
since there are no adjectives with a soft final stem consonant and final stress in Byelorussian. The impetus therefore comes only from the unstressed endings of adjectives with a hard final stem consonant. Thus the adjective acéHнi has:

Neuter nom./acc. sing.

Masc./neut. gen. sing.

Masc./neut. dat. sing.

Fem. gen. sing.

Fem. dat. sing.

Fem. instr. sing.

Fem. prep. sing.

acéнняе
acéнняга
acéннямy
acéнняе (-яй)
acéнняй
acéнняю (-яй)
aсе́нняй

cf. е. g. бе́лае

бе́лага

бе́ламу

бе́лае (-ай)

бе́лай

бе́лаю (-ай)

бе́лай

In the masculine and neuter genitive and dative singular and the feminine genitive singular the use of these endings is reinforced by the fact that these cases of the third person pronoun (from which, of course, the majority of adjectival endings derive, not only in Byelorussian but also in the Slavonic languages generally) have $\mathrm{A}$ for unstressed e, albeit here in accordance with the orthographical rules since $я$ is in the immediate pretonic syllable (яго́, ямý, яé).

In the neuter nominative/accusative singular and feminine genitive singular \& replaces e only in the first syllable of the ending i.e. ee $>$ яе $n$ ot ${ }^{*}$ яя. This is in line with the general principle applying to all inflexional endings that a final e remains unchanged (see above). ${ }^{10}$

One ordinal numeral - трэці, the only one in fact with a soft stem - follows the same pattern as adjectives with a soft stem, since ordinal numerals in general have the same inflexional endings as the adjective declension.

Unlike nouns and adjectives, verb endings do not exhibit anomalous spelling with $\mathrm{A}$ for $\mathrm{e}$ (ë) in unstressed endings. Thus, despite the contrast between, for example, бярэш and пíшаш (2nd person singular, present tense) or бяро́м and пі́шам (1st person plural, present tense), there is no corresponding contrast between, for example, нясе́ш and чыта́еш, нясём and чыта́ем.

The use of $g$ for (ë) in post-stress syllables is therefore confined to certain noun and adjective endings. Since it is possible to define the categories in which this phenomenon occurs it would seem appropriate to amend the orthographical rule concerning the use of \& for e (ë) in unstressed syllables on the following lines:

$\Im$ replaces e (ë) in unstressed position only in the immediate pretonic syllable, except in certain inflexional endings where it appears in post-stress position, viz.:

1) the genitive plural of non-finally stressed nouns with a soft final stem consonant (-яy̆);

2 ) the instrumental singular of non-finally stressed $a$-stem nouns with a soft final stem consonant (-яй);

3 ) the neuter nominative/accusative singular (-яe), masculine and neuter genitive (-яга) and dative (-яму) singular, and the feminine genitive (-яе/-яй), dative (-яй), instrumental (-яю/яй) and prepositional (-яй) singular of adjectives with a soft final stem consonant (all such adjectives having non-final stress). 


\section{NOTES}

1. This feature is often referred to as jakannie, although in fact it is simply a particular instance of akańnie - that occurring after a soft consonant or [j].

2. R. G. A. De Bray, Guide to the Slavonic Languages, revised edition, London, 1969, p. 131.

3. Exceptions to the writing of a for unstressed o, 3 were made in two specific groups of words: firstly international words denoting concepts of the revolutionary era' e.g. сове́т, комуні́зм, большэві́к etc., and secondly, proper names and geographical names of foreign origin e.g. Чэрнъшшэуссти, Шэўчэнка e'tc. As far as the writing of я for unstressed e in the immediate pretonic syllable was concerned the only exceptions were in this latter category e.g. Плеха́наў, Етóp'ey̆ск. (N. I. Hurski, M. H. Bułachaŭ, M. C. Marčanka, Biełaruskaja mova, 2nd ed., I, Minsk, 1958, pp. 91-2.

However, a more recent (1957) edict of the Byelorussian Soviet of Ministers has now largely brought these words into line with the general patiern of the language and they are written with a for unstressed o, and with $\&$ for unstressed $e$ in the immediate pretonic syllable, thus: caвét, камуні́зм, бальшаві́к, Чарнњшэў скі, Бєлінуакі (Hurski, Bułachaŭ, Marčanka, op. cit., pp. 385-6).

The spelling of such words may in any case be considered to constitute a special category. As $K$. Krapiva says: '... loanwords enjoy extraterritorial rights. They are subject to the laws of our [i.e. Byelorussian] morphology, but do not recognise those of phonetics; therefore, when they enter the Byelorussian language they do not merge with it completely but follow 'their own individual course...' (Zbor tvoraŭ, 2, Minsk, 1956, p. 519). For this reason I am confining my observations to native Byelorussian words.

4. See, for example: Hurski, Bułachaŭ, Marčanka, op. cit., p. 91; K. I. Sapialevič and A. K. Sieviarniova, Bietaruskaja mova. Hramatyka, pravapis $i$ raźvićcio movy, 9th ed., Minsk, 1963, p. 9; A. K. Sieviarniova, S. S. Symanskaja, Biełaruskaja mova. Pravapis. Raźvićcio movy, 8th ed., Minsk, 1969, p. 66; M. F. Smarščok, N. L. Žałudzienka, R. P. Kazimirava, Biełaruskaja mova. Cytańnie. Pravapis. Raźvićcio movy, 8th ed., Minsk 1969, p. 182; N. I. Šeǔčyk, A. A. Amialkovič, Biełaruskaja mova, Minsk, 1970, p. 58; V. J. Budźko, S. S. Malaškievič, L. P. Padhajski, Biełaruskaja mova, 2nd ed., Minsk, 1972, p. 15; L. P. Padhajski, A. K. Sieviarniova, Biełaruskaja mova, 4th ed., Minsk, 1973, p. 23; J. M. Kamaroŭski, Bietaruski pravapis, Minsk, 1965, pp. 65-6.

5. J. M. Kamaroŭski, a leading Byelorussian scholar, has written two books on the orthography of Byelorussian, in both of which he mentions these forms (op. cit., pp. 94-5; Bielaruskaja mova. Arfahrafija, Minsk, 1972, pp. 71-2), but in a completely different section from that in which he deals with 'the general orthographical rules of Byelorussian. Furhermore, he does not relate these forms to the rule as exceptions, nor does he atcempt to offer any explanation for their occurrence.

6. Some scholars prefer the terms: 1st declension $(=a$-stem), 2nd declension $(=0$-stem), 3rd declension $(=i$-stem) and heteroclitic (includes consonantstem).

7. In Byelorussian, as in Russian, ë occurs only under stress.

8. Je. F. Karskij, Belorusy, 2, Moscow, 1956, p. 131, does give two examples (quo'ted from P. V. Sejn, 'Belorusskije pesni, sobr. P. V. Šejnom', Zapiski RGO po otdeleniju etnografii, V, St. Petersburg, 1873) showing $\mathrm{f}$ in place of unstressed e (ë) in Byelorussian dialects: каме́нням, เколо́сьям. However, in the absence of any supporting da'ta from the literary language it is highly unlikely that such forms could at any time have been considered acceptable forms in the literary language.

9. Again Karskij, op. cit., p. 122, quotes the occasional dialect form showing r for unstressed e (ë), but for 'the reason advanced in note 8 above there would seem to be no justification for supposing them to have been acceptable literary forms.

10. Equally, therefore, this applies to the corresponding endings of adjectives with a hard final stem consonan't, where final e remains in both stressed and unstressed endings е.g. маладо́е, бе́лае. 